\title{
Analisis Kinerja 3 Saham Bank Syariah di Masa Pandemi COVID-19
}

\author{
Chandra Nugroho, Fathurrohman Rusydi Didin*, Pradigda Satria Wijaya \\ Departemen Manajemen Teknologi, Fakultas Desain Kreatif dan Bisnis Digital, \\ Institut Teknologi Sepuluh Nopember, Surabaya, 60264, Indonesia.
}

\begin{abstract}
ABSTRAK
Pada tahun 2021, perbankan syariah sudah mulai berkembang pesat dan tidak kalah dengan perbankan konvensional. Perbedaan paling mendasar adalah di mana perbankan syariah menggunakan prinsip bagi hasil (profit and loss sharing) dan tidak menggunakan bunga sebagai alat untuk memperoleh pendapatan karena di dalam agama Islam riba itu diharamkan. Penelitian ini bertujuan untuk menganalisis kinerja 3 saham bank syariah di masa pandemi COVID-19 dari Januari 2020 hingga Maret 2021 dengan menggunakan indeks Sharpe. Secara garis besar, ketiga emiten saham (BRIS, BTPS, dan PNBS) memiliki kinerja yang cukup baik selama masa pandemi Covid-19 karena masih di atas indeks Sharpe IHSG. Kinerja terbaik adalah emiten yang memiliki nilai indeks Sharpe paling besar. Berdasarkan analisis yang dilakukan, emiten dengan kinerja paling tinggi adalah BRIS dengan nilai indeks Sharpe 0,05 dan emiten dengan kinerja paling rendah adalah BTPS dengan nilai indeks Sharpe -0.42 .
\end{abstract}

Kata kunci: Indeks Sharpe, Pandemi Covid-19, Saham bank syariah.

C) 2021 Pusat Kajian Halal ITS. All rights reserved.

\section{Pendahuluan}

Perbankan Syariah Modern Kini, perbankan syariah telah mengalami perkembangan yang cukup pesat dan menyebar keseluruh negara bahkan ke negara-negara barat. The Islamic Bank International of Denmark tercatat sebagai bank syariah pertama yang beroperasi di Eropa, yakni pada tahun 1983 di Denmark. Kini bank-bank besar di negara-negara barat seperti Citibank, ANZ Bank, Chase Manhattan Bank, Jardine Fleming telah membuka islamic window agar dapat memberikan jasa-jasa perbankan yang sesuai dengan syariat islam [1].

Hal mendasar yang membedakan antara lembaga keuangan konvensional dengan syariah adalah terletak pada pengembalian dan pembagian keuntungan yang diberikan oleh nasabah kepada lembaga keuangan dan/atau yang diberikan oleh lembaga keuangan kepada nasabah. Kegiatan operasional bank syariah menggunakan prinsip bagi hasil (profit and loss sharing). Bank syariah tidak menggunakan bunga sebagai alat untuk memperoleh pendapatan maupun membebankan bunga atas penggunaan dana dan pinjaman karena bunga merupakan riba yang diharamkan [2].

\footnotetext{
* Corresponding author. Tel: +6282218830240; Fax:-.

Email address: didinfathurrohman.206032@mhs.its.ac.id
} 
Ada dua aspek yang perlu dipertimbangkan oleh manajemen perusahaan dalam pengambilan keputusan keuangan, yaitu tingkat pengembalian (return) dan risiko (risk) keputusan keuangan tersebut. Tingkat pengembalian adalah imbalan yang diharapkan diperoleh di masa mendatang, sedangkan risiko diartikan sebagai ketidakpastian dari imbalan yang diharapkan. Risiko adalah kemungkinan terjadinya penyimpangan dari ratarata dari tingkat pengembalian yang diharapkan yang dapat diukur dari standar deviasi dengan menggunakan statistika. Suatu keputusan keuangan yang lebih berisiko tentu diharapkan memberikan imbalan yang lebih besar, yang dalam keuangan dikenal dengan istilah "High Risk High Return". Ada trade off antara risk dan return, sehingga dalam pemilihan berbagai alternatif keputusan keuangan yang mempunyai risiko dan tingkat pengembalian yang berbeda-beda, pengambilan keputusan keuangan perlu memperhitungkan risiko relatif keputusannya. Untuk mengukur risiko relatif digunakan koefisien variasi, yang menggambarkan risiko per unit imbalan yang diharapkan yang ditunjukkan oleh besarnya standar deviasi dibagi tingkat pengembalian yang diharapkan [3].

Pandemi virus corona (COVID-19) secara resmi ditetapkan sebagai pandemi oleh Organisasi Kesehatan Dunia (WHO) melanda lebih dari 150 negara di dunia. Jumlah orang di seluruh dunia yang terinfeksi masih terus meningkat secara agresif. COVID-19 telah mengubah dunia dalam banyak hal, seperti mengubah cara kita bekerja, belajar, beribadah, bersosialisasi, berolahraga, makan, tidur dan seterusnya. Untuk memperlambat penyebaran COVID-19, setiap orang sangat dianjurkan untuk menjaga jarak (physical distancing), menjaga kebersihan dan menggunakan masker. Berapa lama pandemi akan berlangsung dan dampak ekonominya sulit diprediksi. Pandemi COVID-19 memaksa kita untuk bertahan di tengahtengah ketidakpastian (uncertainities). Namun belakangan pemerintah sudah mulai mencanangkan wacana transisi menuju new normal [4].

Kondisi normal baru harus dihadapi di mana akan ada beberapa kebijakan yang diubah dan dilonggarkan, termasuk soal berinvestasi. Perlu dilakukan adaptasi di mana investor harus menyusun ulang portofolio yang dimiliki. Dalam lingkungan keuangan di tengah pandemi COVID-19, investor harus berhati-hati berportofolio investasi yang holistik dan beragam, sebab bursa saham di seluruh dunia rata-rata mengalami penurunan begitu juga dengan Indeks Harga Saham Gabungan (IHSG) Bursa Efek Indonesia [5].

Untuk melihat kinerja sebuah portofolio kita tidak bisa hanya melihat tingkat return yang dihasilkan portofolio tersebut, tetapi kita juga harus memperhatikan faktor-faktor lain seperti tingkat risiko portofolio tersebut. Dengan berdasarkan pada teori pasar modal, beberapa ukuran kinerja portofolio sudah memasukkan faktor return dan risiko dalam perhitungan. Beberapa ukuran kinerja portofolio yang sudah memasukkan faktor risiko adalah indeks Sharpe dan indeks Treynor.

Penelitian ini bertujuan untuk mengkaji perbandingan kinerja risk dan return dengan 3 emiten bank syariah di Indonesia terhadap dampak pandemi covid-19. Kajian dalam penulisan ini menggunakan beberapa literatur yang terkait dengan tema penelitian yang berkaitan dengan perbandingan kinerja 3 saham bank syariah di masa pandemi COVID-19. Pemilihan emiten pada perbankan karena industri perbankan terus tumbuh secara masif dari tahun ke tahun [6]. Berdasarkan hasil analisa Forecast Error Variance Decomposition 
(FEVD) pada penelitian terdahulu, pembiayaan perbankan syariah memiliki faktor yang dominan terhadap pertumbuhan ekonomi. FEVD bertujuan untuk melihat bagaimana perubahan dalam suatu variabel yang ditunjukkan oleh perubahan error variance dipengaruhi oleh variabel-variabel lainnya [7].

\section{Bahan dan metode}

\subsection{Jenis data}

Obyek analisis yang digunakan adalah bank syariah yang sudah terdaftar di Bursa Efek Indonesia (BEI) meliputi PT. Bank Rakyat Indonesia Syariah Tbk. yang sudah merger pada 1 Februari 2021 dengan PT. Bank BNI Syariah dan PT. Bank Syariah Mandiri menjadi PT. Bank Syariah Indonesia Tbk. Bank hasil merger tersebut menggunakan kode BRIS untuk PT. Bank Rakyat Indonesia Syariah. PT. Bank BTPN Syariah Tbk. menggunakan kode BTPS dan PT. Bank Panin Dubai Syariah Tbk. dengan kode PNBS. Data yang digunakan adalah data pada Bursa Efek Indonesia (BEI) pada bulan Januari 2020 hingga Maret 2021. Data dalam penelitian ini merupakan data sekunder yang didapatkan dari website resmi BEI dan didukung oleh referensi dari literatur yang berkaitan.

\subsubsection{Rasio Keuangan}

Rasio dalam analisis laporan keuangan adalah angka yang menunjukkan hubungan antara unsur dengan unsur lainnya dalam laporan keuangan. Setiap rasio keuangan yang dibentuk memiliki tujuan yang ingin dicapai, sehingga tidak dijumpai batasan yang jelas dan tegas berapa rasio yang terdapat pada setiap aspek yang dianalisis [8].

Pada dasarnya, rasio yang digunakan pada bank tidak jauh berbeda dengan rasio keuangan pada perusahaan nonbank lainnya. Perbedaan yang terdapat antara rasio bank dan perusahaan nonbank terletak pada jenis rasio yang digunakan untuk menilai suatu rasio yang jumlahnya lebih banyak, karena komponen neraca dan laporan laba rugi yang dimiliki bank berbeda dengan laporan neraca dan laporan laba rugi milik perusahaan nonbank. Dalam mengelola dananya, bank membutuhkan kepercayaan masyarakat, sehingga risiko yang dihadapi bank jauh lebih besar ketimbang perusahaan nonbank lainnya dan ada beberapa rasio yang dikhususkan untuk memperhatikan rasio-rasio tersebut [9].

\section{Capital Adequacy Ratio (CAR)}

CAR merupakan rasio yang digunakan untuk mengukur kecukupan modal yang berguna untuk menutupi kemungkinan kegagalan dalam pemberian kredit/pembiayaan [8]. Berdasarkan ketentuan Bank Indonesia (BI), standar CAR adalah minimal sebesar 8\%. Semakin besar rasio CAR maka mencerminkan kemampuan bank yang semakin baik dalam menghadapi kemungkinan risiko kerugian [10]. Rumus yang digunakan untuk menghitung capital adequacy ratio adalah sebagai berikut.

$$
\mathrm{CAR}=\frac{\text { Modal }}{\text { Aset Tertimbang Menurut Risiko (ATMR) }} \times 100 \%
$$




\section{Return on Assets (ROA)}

ROA merupakan rasio yang digunakan untuk mengukur kemampuan manajemen bank dalam memperoleh keuntungan secara keseluruhan [9]. Berdasarkan ketentuan Bank Indonesia (BI), standar ROA adalah di atas 1,5\%. Semakin tinggi rasio ROA suatu bank maka semakin besar tingkat keuntungan yang diperoleh bank dan semakin baik bank tersebut dalam menggunakan asetnya. Rumus yang digunakan untuk menghitung return on assets sebagai berikut.

$$
\text { Return on Assets }=\frac{\text { Laba Sebelum Pajak }}{\text { Rata }- \text { rata Total Aset }} \times 100 \%
$$

\section{Return on Equity (ROE)}

ROE disebut juga dengan laba atas equity atau rasio total asset turnover atau perputaran total asset. Rasio ini mengkaji sejauh mana suatu perusahaan mempergunakan sumber daya yang dimiliki untuk mampu memberikan laba atas ekuitas [11]. Berdasarkan ketentuan Bank Indonesia (BI), standar ROE adalah di atas $12 \%$. Semakin tinggi rasio ROE maka semakin baik bank tersebut dalam menghasilkan laba atas ekuitas yang dimilikinya [12]. Adapun rumus return on equity $(\mathrm{ROE})$ adalah sebagai berikut.

$$
\text { Return on Equity }=\frac{\text { Earning After Tax (EAT) }}{\text { Shareholders } \text { Equity }} \times 100 \%
$$

\section{Beban Operasional terhadap Pendapatan Operasional (BOPO)}

BOPO merupakan rasio yang digunakan untuk mengukur tingkat efisiensi dan kemampuan bank dalam melakukan kegiatan operasionalnya. Berdasarkan ketentuan Bank Indonesia (BI), standar BOPO adalah di bawah 92\%. Semakin rendah rasio BOPO maka akan menunjukkan tingkat efisiensi suatu bank tersebut dalam mengendalikan biaya operasionalnya [10]. Rumus yang digunakan untuk menghitung beban operasional terhadap pendapatan operasional adalah sebagai berikut.

$$
\text { BOPO }=\frac{\text { Total Beban Operasional }}{\text { Total Pendapatan Operasional }} \times 100 \%
$$

\section{Non Performing Loan (NPL)/Non Performing Financing (NPF)}

NPL/NPF merupakan rasio yang digunakan untuk melihat seberapa besar tingkat kredit/pembiayaan bermasalah yang telah disalurkan oleh bank. Semakin tinggi nilai rasio ini, maka semakin menunjukkan bahwa bank tersebut tidak dalam kondisi yang sehat karena NPL/NPF yang tinggi akan menyebabkan laba yang diterima oleh bank akan menurun [10]. Bank Indonesia melalui Peraturan Bank Indonesia (PBI) menetapkan bahwa standar rasio NPL/NPF adalah maksimal 5\%. Non Performing Loan (NPL) merupakan rasio yang digunakan bank umum konvensional, sedangkan Non Performing Financing (NPF) merupakan rasio yang digunakan oleh bank umum syariah. Rumus yang digunakan untuk menghitung NPL adalah: 


$$
\text { Non Performing Loan }=\frac{\text { Kredit Bermasalah }}{\text { Total Kredit }} \times 100 \%
$$

Rumus yang digunakan untuk mencari NPF adalah sebagai berikut:

$$
\text { Non Performing Financing }=\frac{\text { Pembiayaan Bermasalah }}{\text { Total Pembiayaan }} \times 100 \%
$$

\subsubsection{Pengertian Return}

Return atau pengembalian adalah keuntungan yang diperoleh perusahaan, individu dan institusi dari hasil kebijakan investasi yang dilakukan. Return merupakan laba investasi, baik melalui bunga atau deviden [13]. Bisa dihitung dengan rumus berikut.

$$
R=\frac{D_{t}+\left(P_{t}-P_{t-1}\right)}{P_{(t-1)}}
$$

Di mana:

$R_{i, t}=$ return saham ke-i pada periode $\mathrm{t}$

$P_{t} \quad=$ harga saham ke-i pada periode $\mathrm{t}$

$P_{t-1}=$ harga saham ke-i pada periode $\mathrm{t}$

$D_{i, t} \quad=$ dividen saham ke-i pada periode $\mathrm{t}$

\subsubsection{Pengertian Risk}

Secara umum, risiko adalah tingkat ketidak pastian akan terjadinya sesuatu atau tidak terwujudnya sesuatu tujuan pada suatu kurun atau periode waktu tertentu (time period). Risiko bisa juga diartikan sebagai kemungkinan return aktual yang berbeda dengan return yang diharapkan. Investor yang mempunyai sikap enggan terhadap risiko disebut dengan risk averse investor. Investor ini tidak mau mengambil risiko suatu investasi jika investasi tersebut tidak memberikan harapan return yang layak sebagai kompensasi terhadap risiko yang ditanggung investor tersebut. Sikap investor terhadap risiko akan tergantung pada preferensi investor terhadap risiko. Investor yang lebih berani akan memilih risiko investasi yang lebih tinggi, yang diikuti dengan harapan tingkat return yang tinggi pula. Demikian pula sebaliknya, investor yang tidak mau menanggung risiko yang tinggi tentunya tidak akan bisa mengharap kantingkat return yang tinggi. Dalam bidang finansial, risiko sering dihubungkan dengan volatilitas atau penyimpangan/deviasi dari hasil investasi yang akan diterima dengan keuntungan yang diharapkan. Volatilitas merupakan besarnya harga fluktuasi dari sebuah aset. Semakin besar volatilitas aset, maka semakin besar kemungkinan mengalami keuntungan atau kerugian [13].

\subsubsection{Estimasi risiko}

Besaran risiko investasi diukur dari besaran standar deviasi dari return yang diharapkan. Deviasi standar merupakan akar kuadrat dari varians, yang yang menunjukkan seberapa besar penyebaran variabel random di antara rata-ratanya; semakin besar penyebarannya, semakin besar varians atau deviasi standar investasi tersebut [13]. 
Rumus varians dan deviasi standar:

$$
\begin{aligned}
& \sigma^{2}=\sum\left[R_{i}-E(R)\right]^{2} p r_{i} \\
& \sigma=\left(\sigma^{2}\right)^{1 / 2}
\end{aligned}
$$

Dalam hal ini:

$\sigma^{2} \quad=$ varians return

$\sigma \quad=$ standar deviasi

$\mathrm{E}(\mathrm{R}) \quad$ = return yang diharapkan dari suatu sekuritas

$R_{i} \quad=$ return ke-i yang mungkin terjadi

$p r_{i} \quad=$ probabilitas kejadian return ke-i

\section{Coefficient of variation}

Digunakan untuk menghitung expected return yang berbeda dengan rumus sebagai berikut.

$$
c v=\frac{\sigma}{E(R)}
$$

Di mana:

$\mathrm{CV}$ = coefficient of variation

$\sigma \quad=$ deviasi standar

$\mathrm{E}(\mathrm{R})$ = return yang diharapkan dari suatu sekuritas

\subsubsection{Pengukuran kinerja menggunakan indeks Sharpe}

Penilaian kinerja portofolio saham dengan menggunakan metode Sharpe dilakukan dengan cara mengurangi expected return saham atau portofolio dengan risk free rate of return lalu dibagi dengan deviasi standar return portofolio [14].

$$
S p=\frac{R i-R f}{\sigma i}
$$

Di mana:

$\mathrm{Ri}=$ Expected return saham atau portofolio

$\mathrm{Rf}=$ Risk free of return

$\sigma i=$ Standar deviasi return

\subsection{Metode}

Metode yang digunakan adalah analisa deskriptif dan komparatif terhadap laporan keuangan tahunan dari ketiga emiten saham bank syariah. Perhitungan risk and return menggunakan single index model tanpa hipotesis. Pengukuran kinerja pada masing-masing emiten menggunakan penghitungan indeks Sharpe.

\section{Hasil dan pembahasan}

\subsection{Hasil}

\subsubsection{Rasio keuangan perbankan}

Analisis laporan keuangan adalah suatu proses penelitian laporan keuangan beserta unsurunsurnya yang bertujuan untuk mengevaluasi dan memprediksi kondisi keuangan 
perusahaan atau badan usaha dan juga mengevaluasi hasil-hasil yang telah dicapai perusahaan atau badan usaha pada masa lalu dan sekarang. Laporan keuangan dibuat untuk mengetahui gambaran tentang posisi suatu keuangan pada perusahaan serta hasil-hasil yang diperoleh oleh perusahaan [15].

Dalam penelitian kali ini peneliti akan melakukan analisa komparatif pada laporan keuangan di 3 emiten bank syariah yang terdaftar di BEI, berdasarkan 9 rasio dalam laporan keuangan tahunan. Data rasio yang tercantum dalam masing-masing laporan keuangan tahunan dapat dilihat pada Tabel 1.

Tabel 1. Rasio Keuangan Emiten Saham BRIS, BTPS, dan PNBS

\begin{tabular}{|l|r|r|r|r|r|r|}
\hline \multirow{2}{*}{ RASIO } & \multicolumn{2}{c|}{ BRIS } & \multicolumn{2}{c|}{ BTPS } & \multicolumn{2}{c|}{ PNBS } \\
\cline { 2 - 7 } & $\mathbf{2 0 2 0}$ & $\mathbf{2 0 1 9}$ & $\mathbf{2 0 2 0}$ & $\mathbf{2 0 1 9}$ & $\mathbf{2 0 2 0}$ & $\mathbf{2 0 1 9}$ \\
\hline KPMM & $19,04 \%$ & $23,51 \%$ & $25,19 \%$ & $14,46 \%$ & $31,43 \%$ & $\mathbf{2 5 , 2 6 \%}$ \\
\hline Aset Bermasalah Berbanding Aset & $3,79 \%$ & $0,44 \%$ & $0,55 \%$ & $3,42 \%$ & $3,34 \%$ & $5,49 \%$ \\
\hline $\begin{array}{l}\text { Aset Produktif Bermasalah Berbanding } \\
\text { Aset Produktif }\end{array}$ & $2,33 \%$ & $0,68 \%$ & $0,92 \%$ & $3,42 \%$ & $3,34 \%$ & $3,46 \%$ \\
\hline CKPN & $2,64 \%$ & $0,77 \%$ & $1,63 \%$ & $2,66 \%$ & $2,70 \%$ & $1,81 \%$ \\
\hline NPL gross & $3,24 \%$ & $0,78 \%$ & $1,15 \%$ & $3,81 \%$ & $3,38 \%$ & $5,22 \%$ \\
\hline NPL nett & $1,77 \%$ & $0,45 \%$ & $0,53 \%$ & $2,80 \%$ & $2,45 \%$ & $3,38 \%$ \\
\hline ROA & $0,81 \%$ & $1,29 \%$ & $1,01 \%$ & $0,25 \%$ & $0,06 \%$ & $0,31 \%$ \\
\hline ROE & $5,03 \%$ & $7,05 \%$ & $5,68 \%$ & $1,08 \%$ & $0,01 \%$ & $1,57 \%$ \\
\hline BOPO & $91,01 \%$ & $89,17 \%$ & $91,72 \%$ & $97,74 \%$ & $99,42 \%$ & $96,80 \%$ \\
\hline
\end{tabular}

Setiap perusahaan pasti memiliki risiko aset bermasalah, baik itu aset produktif ataupun non produktif. Idealnya, non-produktif ataupun produktif memiliki nilai rasio di atas $2 \%$. Arti dari $2 \%$ adalah minimal aset bermasalah pada sebuah perusahaan (aset produktif ataupun total aset) adalah $2 \%$ dari total aset yang dimiliki. Jika total aset adalah 100 , maka maksimal aset yang bermasalah adalah 2. Pada Tabel 1 banyak ban BTPS yang memiliki rasio aset bermasalah paling baik karena terkoreksi di bawah $2 \%(0,55 \%$ untuk aset total dan 0,92 untuk aset produktif).

Untuk mengatasi risiko-risiko tersebut, sebuah perusahaan diharuskan memiliki KPMM dan CKPN. KPMM adalah kemampuan bank untuk mengatasi risiko kerugian, sedangkan CKPN adalah aset cadangan untuk mengatasi risiko kerugian dalam aktiva produktif [16]. Pada Tabel 1 , semua perusahaan miliki KPMM di atas nilai ideal yaitu $8 \%$. Artinya, ketiga perusahaan diatas memiliki kemampuan untuk membayar segala macam kerugian yang akan dialami di kemudian hari (dalam tahun periode). Sedangkan untuk CKPN dari BTPS dan BRIS memiliki nilai yang lebih tinggi dari pada risikonya. Ini menandakan bahwa perusahaan tersebut mampu membayar kerugian dari pada aktiva produktifnya.

Pada dasarnya NPL gambaran umum terkait jumlah kredit bermasalah pada sebuah perusahaan, semakin tinggi nilainya semakin tinggi pula angka kredit yang bermasalah pada sebuah perusahaan. Perbedaan utama dari pada NPL GROSS dan NPL NET adalah NPL GROSS mencatat semua aset bermasalah, baik dari aset kurang lancar sampai dengan aset macet. Sedangkan NPL NETT menggambarkan hanya kredit bermasalah dengan kategori kredit macet. Pada Tabel 1 terlihat bahwa hanya BTPS saja yang meiliki nilai NPL, baik itu 
gross ataupun nett yang baik di angka $1,15 \%$ dan $0,53 \%$ dari nilai standarnya yaitu $2 \%$ dan $1 \%$ (gross dan net). BTPS memiliki kemampuan untuk membayar setiap permasalahan pada kreditnya (mulai dari kredit kurang lancar sampai kredit macetnya) [16].

Untuk analisis laba yang diperoleh dapat dilihat dari 2 aspek yaitu, ROA dan ROE. Dengan pemahaman mudahnya yaitu ROA adalah laba untuk perusahaan dan ROE adalah laba untuk investor. Pada Tabel 1 menunjukan bahwa ketiga perusahaan tersebut belum bisa menghasilkan laba yang cukup baik itu untuk peruhahaan itu sendiri ataupun untuk investor. Terbukti PNBS memiliki rasio yang cukup kecil (dengan standar yaitu 1,5 untuk ROA dan $12 \%$ untuk ROE). Walaupun demikian, untuk perusahaan BTPS dan BRIS sudah berusaha untuk mendekati nilai tersebut.

BOPO adalah perbandingan antara beban dan pendapatan operasional. Pada rasio BOPO, semakin kecil rasio maka sebuah perusahaan akan memungkinkan mendapatkan laba yang lebih tinggi. Idealnya nilai BOPO adalah di bawah 92\%. Apabila mendekati $100 \%$, maka perusahaan tersebut mengalami ancaman kerugian yang sangat besar [16]. Pada Tabel 1 menunjukan bahwa BRIS dan BTPS sudah memiliki kinerja yang cukup baik karena rasionya sudah di bawah mencapai angka 91\% atau sudah di bawah rasio ideal. Dan menunjukkan kemajuan yang sangat signifikan dari tahun sebelumnya. Hal ini menandakan bahwa tahun 2020, kedua perusahaan tersebut bekerja dengan baik dalam memperoleh pendapatan yang lebih tinggi dari tahun sebelumnya.

Pada analisa komparatif Tabel 1, terlihat BTPS memiliki rasio laporan keuangan yang lebih baik dari pada PNBS dan BRIS. Hal ini dikarenakan BTPS memiliki kemampuan untuk mengatasi kemungkinan permasalahan yang akan terjadi terkait realisasi aset. BTPS memiliki kemampuan menghasilkan laba bersih untuk investor yang masih kurang atau di bawah angka idealnya yaitu 12\%. Namun jika dilihat dari pada laporan keuangan sebelumnya (2019), maka BTPS memiliki kemampuan untuk berkembang karena mengalami kenaikan pada rasio-rasio laporan keuangan. Sedangkan 2 emiten lainya tidak menunjukan kenaikan yang signifikan dan bahkan ada beberapa rasio yang mengalami sedikit penurunan dari tahun sebelumnya.

Jika dikaitkan dengan pandemi COVID-19 yang berlangsung sejak Februari 2020 hingga saat ini, terlihat tidak ada penurunan rasio pada laporan keuangan yang signifikan. Pada sisi lain, rasio KPMM dari ketiga emiten tersebut mengalami peningkatan, walaupun dari segi kinerja tidak mengalami peningkatan yang signifikan.

\subsubsection{Return}

Pergerakan persentase rate of return emiten saham BRIS, BTPS, dan PNBS Januari 2020Maret 2021 ditunjukkan oleh Tabel 2. Berdasarkan tabel tersebut, dapat dilihat bahwa emiten saham BRIS mengalami rate of return paling rendah pada bulan Februari 2020 sebesar $-40,91 \%$, sedangkan rate of return paling tinggi terjadi pada bulan Agustus 2020 dengan nilai sebesar $44,04 \%$. Emiten saham BTPS mengalami penurunan rate of return paling rendah pada bulan Maret 2020 sebesar 76,53\%, sedangkan rate of return paling tinggi terjadi pada Bulan Mei 2020. Emiten saham PNBS tidak mengalami pergerakan sejak Januari 2020 hingga Oktober 2020, saham PNBS baru mengalami pergerakan kembali di Bursa Efek 
Indonesia pada bulan November 2020. Emiten saham PNBS mengalami penurunan rate of return paling rendah pada bulan Januari 2021 sebesar -26,56\%, sedangkan rate of return paling tinggi yaitu terjadi pada bulan Februari 2021. Berikutnya pergerakan persentase rate of return emiten saham BRIS, BTPS, dan PNBS Januari 2020-Maret 2021 dapat dilihat pada Gambar 1.

Tabel 2. Pergerakan persentase rate of return emiten saham BRIS, BTPS, dan PNBS Januari 2020-Maret 2021

\begin{tabular}{|l|r|r|r|}
\hline Periode & \multicolumn{1}{|c|}{ BRIS } & \multicolumn{1}{c|}{ BTPS } & \multicolumn{1}{c|}{ PNBS } \\
\hline Jan-20 & $-6,45 \%$ & $3,63 \%$ & $0,00 \%$ \\
\hline Feb-20 & $-40,91 \%$ & $-14,63 \%$ & $0,00 \%$ \\
\hline Mar-20 & $-14,29 \%$ & $-76,53 \%$ & $0,00 \%$ \\
\hline Apr-20 & $0,00 \%$ & $2,74 \%$ & $0,00 \%$ \\
\hline May-20 & $34,67 \%$ & $25,35 \%$ & $0,00 \%$ \\
\hline Jun-20 & $2,60 \%$ & $9,43 \%$ & $0,00 \%$ \\
\hline Jul-20 & $42,22 \%$ & $7,25 \%$ & $0,00 \%$ \\
\hline Aug-20 & $44,04 \%$ & $11,54 \%$ & $0,00 \%$ \\
\hline Sep-20 & $-29,33 \%$ & $-17,99 \%$ & $0,00 \%$ \\
\hline Oct-20 & $38,46 \%$ & $10,27 \%$ & $0,00 \%$ \\
\hline Nov-20 & $12,94 \%$ & $10,41 \%$ & $27,54 \%$ \\
\hline Dec-20 & $38,00 \%$ & $-12,27 \%$ & $16,87 \%$ \\
\hline Jan-21 & $5,74 \%$ & $-11,76 \%$ & $-26,56 \%$ \\
\hline Feb-21 & $16,67 \%$ & $16,59 \%$ & $36,00 \%$ \\
\hline Mar-21 & $-29,69 \%$ & $-17,82 \%$ & $-26,25 \%$ \\
\hline
\end{tabular}

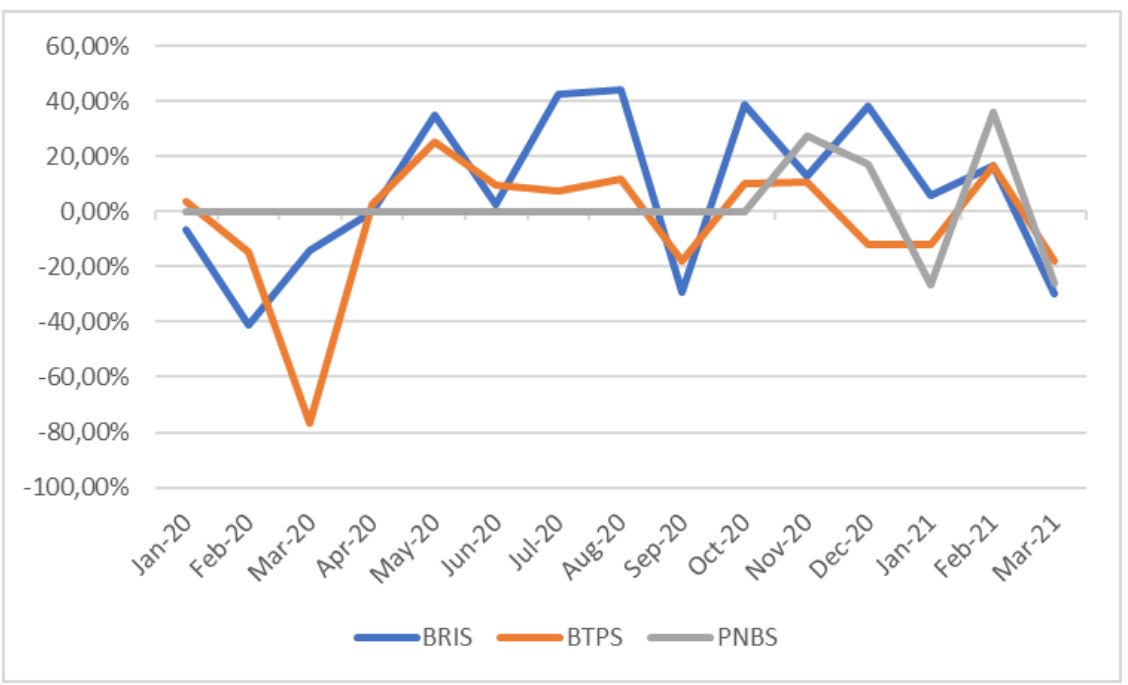

Gambar 1. Pergerakan persentase rate of return emiten saham BRIS, BTPS, dan PNBS Januari 2020 - Maret 2021

Berdasarkan Gambar 1, dapat dilihat bahwa garis yang berwarna biru adalah emiten saham BRIS, garis berwarna oranye adalah emiten saham BTPS, dan garis berwarna abu-abu emiten saham PNBS. Emiten saham BRIS mengalami penurunan yang signifikan pada bulan Februari 2020 bertepatan dengan datangnya virus COVID-19 di Indonesia. Pada bulan Maret hingga April, emiten BRIS dapat bangkit dan menghasilkan rate of return yang positif pada bulan 
berikutnya. Emiten saham BTPS mengalami penurunan yang signifikan pada bulan Maret 2020, BTPS dapat kembali menghasilkan rate of return yang positif pada bulan April hingga Mei 2020. Emiten saham PNBS baru kembali aktif di bursa pada Bulan November 2020 dan menghasilkan rate of return yang positif, namun pada bulan Januari mengalami penurunan yang signifikan.

Di antara ketiga emiten saham, BTPS mengalami penurunan persentase rate of return paling tinggi yang terjadi pada bulan Maret 2020 jika dibandingkan dengan BRIS dan PNBS. Emiten saham yang memimiliki kenaikan persentase rate of return paling tinggi adalah BRIS yang terjadi pada bulan Agustus 2020.

\subsubsection{Risk}

Tabel 3. Hasil perhitungan risk emiten saham BRIS, BTPS, dan PNBS Januari 2020 - Maret 2021

\begin{tabular}{|l|r|r|r|}
\hline & \multicolumn{1}{|c|}{ BRIS } & \multicolumn{1}{|c|}{ BTPS } & \multicolumn{1}{|c|}{ PNBS } \\
\hline Mean return & $7,64 \%$ & $-3,59 \%$ & $1,84 \%$ \\
\hline Standar deviasi & $26,36 \%$ & $23,43 \%$ & $15,67 \%$ \\
\hline Coefficient of Variance (CV) & 3,45 & $-0,15$ & 0,12 \\
\hline
\end{tabular}

Berdasarkan dari Tabel 3, standar deviasi terbesar ada pada emiten BRIS dengan nilai $26 \%$ dan standar deviasi terkecil ada pada emiten PNBS dengan nilai 16\%. Nilai CV terbesar ada pada emiten BRIS yaitu 3,45 dan CV terkecil ada pada emiten PNBS dengan nilai 0,12. Dari data tersebut, dapat dilihat bahwa ketika nilai standar deviasi dan CV besar maka tingkat risiko dari saham tersebut lebih besar dari saham-saham lainnya. Pandemi ini tentunya memberikan risiko yang cukup fluktuatif bagi emiten bank syariah. Berbeda dengan periode tahun 2008-2012, salah satu emiten saham perbankan yaitu Bank Rakyat Indonesia yang merupakan induk dari perusahaan Bank BRI Syariah yang merupakan salah satu penyusun Bank Syariah Indonesia, memiliki risiko paling rendah dari semua emiten di indeks saham LQ45 [17].

\subsubsection{Indeks Sharpe}

Tabel 4. Hasil perhitungan indeks Sharpe emiten Saham BRIS, BTPS, dan PNBS terhadap IHSG Januari 2020 - Maret 2021

\begin{tabular}{|l|r|r|r|}
\hline & Rata-rata return & Standar deviasi & \multicolumn{1}{|c|}{ Indeks Sharpe } \\
\hline BRIS & $7,64 \%$ & $26,36 \%$ & 0,05 \\
\hline BTPS & $-3,59 \%$ & $23,43 \%$ & $-0,42$ \\
\hline PNBS & $1,84 \%$ & $15,67 \%$ & $-0,28$ \\
\hline IHSG & $-0,11 \%$ & $6,85 \%$ & $-0,93$ \\
\hline Risk free & $6,30 \%$ & \multicolumn{2}{|}{} \\
\hline
\end{tabular}

Indeks Sharpe emiten saham BRIS, BTPS, dan PNBS dapat dilihat pada Tabel 4. Berdasarkan data pada Tabel 4, emiten saham BRIS memiliki rata-rata return paling tinggi jika dibandingkan dengan emiten saham BTPS dan PNBS. Pada kasus kali ini, risk free yang dipakai adalah sebesar 6,30\% [18]. Dalam melihat kinerja suatu emiten saham maka dapat dilihat dari indeks Sharpe, indeks Sharpe pada setiap emiten dibandingkan dengan indeks 
Sharpe dari Indeks Harga Saham Gabungan (IHSG) dari Januari 2020 hingga Bulan Maret 2021. Emiten saham BRIS memiliki indeks Sharpe 0,05, kemudian emiten saham BTPS memilki nilai indeks Sharpe sebesar -0,42, dan emiten saham PNBS memiliki indeks Sharpe senilai $-0,28$. Ketiga emiten saham bank syariah tersebut memiliki kinerja yang cukup baik di masa pandemi Covid-19 saat ini, hal ini dapat dilihat dari nilai indeks Sharpe masing-masing emiten yang lebih besar dari indeks Sharpe pasar atau IHSG yag memiliki nilai -0,93.

\subsection{Diskusi}

Peneliti tidak menghitung pengaruh antara pandemi COVID-19 terhadap rasio keuangan, risk and return, dan kinerja saham. Peneliti hanya menganalisis bagaimana kondisi rasio keuangan, risk and return, dan kinerja saham dari masing-masing emiten selama pandemi COVID-19. Data yang digunakan dalam rasio keuangan adalah laporan tahunan 2020, sedangkan pergerakan rate of return diihitung sejak Januari 2020 hingga Maret 2021. Hal ini bertujuan untuk melihat bagaimana pergerakan persentase rate of return, risiko dan kinerja pada masing-masing emiten sebelum pandemi COVID-19 datang ke Indonesia hingga bulan Maret 2021.

Kinerja dari emiten BRIS ini sejalan dengan kinerja dari perusahaan induk sebelum dilakukan merger yaitu PT. Bank Rakyat Indonesia Tbk., yang memiliki kinerja paling baik ketiga pada periode tahun 2013-2017 [19]. Pada tahun 2016, Bank Mandiri sebagai salah satu induk dari Bank Syariah Mandiri saat sebelum dilakukan merger, memiliki kinerja yang cukup baik dan dapat dijadikan pertimbangan untuk portofolio investasi [20]. Bank induk dari penyusun Bank Syariah Indonesia lainnya adalah Bank BNI. Bank BNI memiliki kinerja saham yang cukup baik pada tahun 2018-2019 [21]. Kinerja yang cukup baik dari perusahaan induk penyusun bank syariah Indonesia tentunya menjadi sebuah pertimbangan masyarakat dalam membeli emiten BRIS untuk berinvestasi. Hal ini berdampak pada melambungnya harga saham BRIS di masa pandemi COVID-19.

\section{Kesimpulan}

Dari analisis rasio keuangan yang sudah dilakukan dapat disimpulkan bahwa walaupun ke 3 emiten tersebut memiliki aset diatas ideal. BTPS memiliki kemampuan lebih untuk mengatasi kemungkinan permasalahan yang akan terjadi terkait realisasi aset. Pada sisi lain, BTPS menghasilkan laba bersih untuk investor masih dibawah angka idealnya yaitu $12 \%$. Namun jika dilihat dari pada laporan keuangan sebelumnya (2019), maka BTPS memiliki kemampuan untuk berkembang karena mengalami kenaikan terkait rasio-rasio laporan keuangan yang cukup stabil. Jika dikaitkan dengan pandemi COVID-19 yang berlangsung sejak Februari 2020 hingga saat ini, tidak ada penurunan rasio pada laporan keuangan yang signifikan. Pada sisi lain, rasio KPMM dari ketiga emiten tersebut mengalami peningkatan, walau apabila dilihat dari kinerja tidak mengalami peningkatan yang signifikan.

Emiten saham yang memiliki persentasi rate of return paling tinggi adalah emiten BRIS (44,04\%) pada bulan Agustus 2020, sedangkan emiten saham yang memiliki persentase rate of return paling rendah adalah emiten BTPS pada bulan Maret $2020(-76,53 \%)$. Selama masa pandemi COVID-19, masing-masing saham mengalami pergerakan yang fluktuatif pada setiap bulannya. Apabila dilihat dari segi risk, maka dapat disimpulkan bahwa emiten saham 
yang memiliki risiko paling tinggi selama pandemi COVID-19 adalah emiten BRIS dengan standar deviasi $26,36 \%$ dan CV 3,45. Emiten saham yang memilki risiko paling rendah adalah PNBS dengan standar deviasi 15,67\% dan CV 0,12.

Ketiga saham syariah memiliki kinerja yang cukup baik selama masa pandemi COVID-19, semuanya memiliki nilai indeks Sharpe yang lebih besar dari indeks Sharpe IHSG yang memiliki nilai. Emiten yang memiliki kinerja paling baik selama pandemi COVID-19 adalah emiten saham BRIS dengan indeks Sharpe 0,05 dan emiten yang memiliki kinerja paling rendah adalah emiten saham BTPS dengan indeks sharpe $-0,42$. Penelitian ini memiliki beberapa keterbatasan dan memiliki potensi untuk dikembangkan dalam penelitian lanjutan.

\section{Ucapan terima kasih}

Ucapan terima kasih kami ucapkan kepada Allah SWT tanpa berkat dan hiadayahnya tidak akan bisa menyelesaikan tulisan ini, dan kami ucapkan terima kasih kepada rekan-rekan dan keluarga yang tidak dapat kami ucapkan satu persatu atas doa dan support kepada kami yang diberikan untuk menyelesaikan tulisan kami ini.

\section{Referensi}

[1] E. Trolle-schultz, "How the first Islamic bank was established in Europe," dalam Islamic banking and finance, Butterworths editorial staff, 1986.

[2] Muhamad, Manajemen Bank Syari'ah, Edisi kedua. Yogyakarta: UPP STIM YKPN, 2005.

[3] S. K. Asnawi dan C. Wijaya, Riset Manajemen Keuangan. Jakarta: Graha Media, 2007.

[4] D. Tambunan, "Investasi saham di masa pandemi COVID-19," Widya Cipta: Jurnal Sekretari dan Manajemen, vol. 4, no. 2, pp. 117-123, 2020, doi: 10.31294/widyacipta.v4i2.8564.

[5] C. C. Ngwakwe, "Effect of COVID-19 pandemic on global stock market values: A differential analysis," Acta Universitatis Danubius Oeconomica, vol. 16, no. 2, pp. 255269, 2020.

[6] P. Varadharajan dan Dr. P. Vikkraman, "Construction of equity portfolio of banking sector with reference to the sharpe index model," The Research Journal of United Institute of Management, vol. 2, no. 2, pp. 11-20, 2011.

[7] S. el Ayyubi, L. Anggraeni, dan A. D. Mahiswari, "Pengaruh bank syariah terhadap pertumbuhan ekonomi di Indonesia," Al-Muzara'ah, vol. 5, no. 2, pp. 88-106, 2018, doi: $10.29244 /$ jam.5.2.88-106.

[8] Jumingan, Analisis Laporan Keuangan. Jakarta: Bumi Aksara, 2011.

[9] Kasmir, Manajemen Perbankan. Jakarta: Raja Grafindo Persada, 2014.

[10] J. Suwandi, "Pengaruh CAR, NPL, BOPO dan LDR terhadap ROA pada BUSN devisa," Jurnal IImu dan Riset Manajemen, vol. 6, no. 7, 2017. 
[11] I. Fahmi, Manajemen Perbankan Konvensional dan Syariah. Jakarta: Mitra Wacana Media, 2015.

[12] D. Umardani dan A. Muchlish, "Analisis perbandingan kinerja keuangan bank syariah dan bank konvensional di Indonesia," Jurnal Manajemen dan Pemasaran Jasa, vol. 9, no. 1, 2016.

[13] J. C. Van Horne dan Jr. John M. Wachowicz, Fundamental of Financial Management, Edisi ke-13. Pearson Education, 2007. doi: 10.4135/9781412976169.n18.

[14] Z. Zubir, Manajemen Portofolio Penerapannya dalam Investasi Saham. Jakarta: Salemba Empat, 2011.

[15] R. Satria, "Analisis laporan keuangan untuk melihat kinerja perusahaan pada PT. Darma Henwa Tbk.," Jurnal Sekuritas, vol. 1, no. 2, pp. 89-102, 2017.

[16] D. Hardianti dan M. Saifi, "Analisis perbandingan kinerja keuangan bank umum konvensional dan bank umum syariah berdasarkan rasio keuangan bank (studi pada bank umum konvensional dan bank umum syariah yang terdaftar dan diawasi oleh Otoritas Jasa Keuangan (OJK) periode 2013 - 2016)," Jurnal Administrasi Bisnis (JAB), vol. 60, no. 2, pp. 10-18, 2018.

[17] E. Arisondha, "Analisis perbandingan kinerja portofolio saham dengan metode Sharpe, Treynor dan Jensen (studi kasus indeks LQ 45 di Bursa Efek Indonesia periode 2008 2012)," Jurnal Dinamika Manajemen, vol. 1, no. 4, 2013.

[18] P. Fernandez, E. de Apellániz, dan J. F. Acín, "Survey: Market risk premium and riskfree rate used for 81 countries in 2020," SSRN Electronic Journal, pp. 1-15, 2020, doi: $10.2139 /$ ssrn.3560869.

[19] W. Wihardi dan A. Lutfi, "Pembentukan portfolio optimal untuk berinvestasi pada saham perusahaan perbankan di Bursa Efek Indonesia dengan metode Sharpe, Treynor dan Jensen," Jurnal Manajemen Bisnis Dan Kewirausahaan, vol. 4, no. 3, pp. 74-80, 2020.

[20] M. Susilowati, R. Rahmawati, dan A. Prahutama, "Analisis kinerja portofolio optimal dengan metode mean-gini," Jurnal Gaussian, vol. 5, no. 3, pp. 497-504, 2016, [Online]. Available: http://ejournal-s1.undip.ac.id/index.php/gaussian.

[21] D. Susilowati, Juwari, dan C. Novadinda, "Analisis kinerja portofolio saham dengan menggunakan metode indeks Sharpe, Treynor, dan Jensen pada kelompok saham indeks SRI-KEHATI di Bursa Efek Indonesia," Jurnal GeoEkonomi, vol. 11, no. 1, 2020. 